\title{
Effect of Earnings Management on Cost of Debt Before and After International Standard Financial Reporting Implementation
}

\author{
Chandra Situmeang \\ Department of Accounting \\ Universitas Sumatera Utara \\ Medan, Indonesia \\ chandrasitumeang@gmail.com
}

Erlina

Department of Accounting

Universitas Sumatera Utara

Medan, Indonesia

erlinaroesli@yahoo.co.id

\author{
Azhar Maksum \\ Department of Accounting \\ Universitas Sumatera Utara \\ Medan, Indonesia \\ azharmaksum16@gmail.com
}

\author{
Tavi Supriana \\ Department of Accounting \\ Universitas Sumatera Utara \\ Medan, Indonesia \\ tavihutasuhut@yahoo.co.id
}

\begin{abstract}
A business environment with high competition requires higher efficiency, not just operating efficiency but also the funding efficiency. One of the causes of funding inefficiency is the high cost of debt as a result of earnings management practices that can reduce investor confidence in the company's financial statements. The practice of earnings management has attracted practitioners, researchers, and regulators by develop various detecting models and develop standards such as International Financial Reporting Standard (IFRS). To analyze influence the effect of earnings management on cost of debt, this study uses three approaches: competing-component model, business model, and discretionary revenue model. The approach used is to review the capability of the linear regression model that is formed and to perform comparative analysis among the regression models formed by data from manufacturing companies listed in the Indonesia Stock Exchange for the years 2007-2011 as data before the IFRS implementation and 20122015 for data after the IFRS implementation. Based on the results of data processing obtained evidence that earnings management negatively affect the cost of debt using the three approaches but the model formed with business model approach has stronger than the regression equation formed with other models. When compared to the period before and after the implementation of IFRS, seen earnings management practices have decreased and the effect on the cost of debt becomes smaller.
\end{abstract}

\section{Keywords - Earning Management; Cost of Debt; IFRS}

\section{INTRODUCTION}

At this time there is increased intensity of competition between companies. The main cause of the increase in competition is because competition has occurred not only within a country but also between countries. Regulatory deregulation contributes to increased competition as it removes the usual barriers to inter-state trade. This makes all companies must be able to improve their competitiveness in order to survive and thrive in global competition.

Only efficient companies can win the competition. Such efficiency can be sourced from the technical process of production to the ability to obtain the most efficient funding. Efforts to achieve efficiency regarding production process is the field of non-accounting studies. In addition to production efficiency, management needs to focus attention on funding efficiency. Theoretically, all funds used by the company either paid by the owner or the debt obtained from the creditor bear certain costs, hereinafter referred to as Cost of Capital $(\mathrm{CoC})$. This means that $\mathrm{CoC}$ will be one of the cost components that will determine the company's ability to compete.

TABLE I. I LENDING RATE AND REAL INTEREST RATE 2015

\begin{tabular}{|l|l|l|}
\hline \multicolumn{1}{|c|}{ Country } & \multicolumn{1}{|c|}{ Lending Rate (\%) } & Real Interest Rate (\%) \\
\hline Indonesia & 12.663 & 8.089 \\
\hline Malaysia & 4.585 & 4.980 \\
\hline Thailand & 6.563 & 3.650 \\
\hline Singapore & 5.350 & 6.330 \\
\hline $\begin{array}{l}\text { United States of } \\
\text { America }\end{array}$ & 3.260 & 2.160 \\
\hline Japan & 1.143 & -0.090 \\
\hline Brazil & 43.958 & 33.416 \\
\hline Russia & 15.717 & 6.996 \\
\hline India & 10.008 & 7.956 \\
\hline China & 4.350 & 4.810 \\
\hline South Africa & 9.417 & 5.252 \\
\hline
\end{tabular}


CoC consists of two components, namely the cost component of its own capital, hereinafter referred to as the Cost of Equity $(\mathrm{CoE})$ and the cost component of the debt obtained from the creditor, which we shall refer to as the Cost of Debt (CoD). The COD value in a country can be measured by the lending rate in that country. Table 1 is a summary of data published by World Bank through http://data.worldbank.org related to lending rate data and real interest rate. Based on these data, Indonesia's real interest rate was ranked 10 th $(8.089 \%)$ of the 11 countries. Indonesia's real interest rate is only smaller than that of Brazil in that period (in 2015) experienced considerable economic turmoil.

Although (1) uses the old data, but can provide a fairly good explanation why the cost of borrowing in Indonesia is relatively high. The results of this study indicate that Indonesia is ranked in the last of 34 countries studied in the informative earnings accounting (earning opacity). These results reinforce the notion that there is a high probability of $\mathrm{CoD}$ as a result of high investment risk within the company. The risk in this case is the risk as a result of the quality of information published by the company. The company does not provide information that enables investors to forecast the beliefs about the future of the company so that investors increase the $\mathrm{CoD}$ as compensation for the risk of unclear information.

Earning Management (EM) activity is theoretically one of the causes of the lack of informativeness of financial statements. This is still a debate because some research concludes that EM Improve the quality of information. Improving the quality of these financial statements because management includes information related to prospects of the company, where such information is not disclosed or incorporated into the financial statements if only following the usual standards. The action of EM in this definition is then known as beneficial earning management. However, this is only possible in capital markets with high levels of information efficiency. In fact, on the other hand, few studies have concluded that the Indonesian capital market is efficient (2) while most research concludes that the Indonesian capital market is inefficient [(3); (4)]. Low market efficiency levels indicate that there is information asymmetry in which management has better information than others.

Earning Management will reduce earning quality. Earning quality can reflect risk, where low earning quality is a high risk reflection for capital owners who wish to invest their funds within the firm (5). Some studies such as (6) and (7) attempt to distinguish them by examining the relationship between the two. The study obtained results consistent with the theory that the actions taken by management in order to direct the rate of profit at the desired level will degrade the quality of information from the reported earnings in the financial statements.

One of the causes that allegedly increases the information asymmetry is the difference in standards used in various countries. In response to this there is an attempt to reduce information asymmetry by designing and encouraging the implementation of International Financial Reporting of IFRS Standards). This research (8) who sampled companies in
Europe concluded that IFRS implementation could reduce information asymmetry and improve the reliability of financial statements in predicting future circumstances. The results of this study are in line with (9) but contrary to the results of (10) studies concluding that for companies listed in the Brazil stock exchange the IFRS implementation does not provide a significant influence on reducing information asymmetry. This difference is most likely due to differences in the level of market efficiency between Europe and Brazil. Implementation studies of IFRS implications, especially in relation to the relationship of information asymmetry with various other variables, are very strong to be done in the Indonesian capital market.

Based on this research, this study aims to examine whether there are differences in the effect of earning management practices on cost of debt before and after the implementation of IFRS. This is interesting enough to examine because one of the objectives of IFRS implementation is to reduce the uncertainty of information resulting in increased cost of funds including debt costs.

\section{LITERATURE REVIEW}

\section{A. Cost of Debt (CoD)}

Cost of Debt $(\mathrm{CoD})$ refers to the cost of debt borne by the company either from long-term debt or short-term debt. The cost of debt can be seen directly from the interest rate charged to the overall debt of the company. (11) Explains that the interest rate charged on a debt can be viewed directly as a borrowing cost. Accumulatively, CoD can be easily obtained in the financial statements recorded as interest expense. The interest expense arises from the interest paid by the company to the lender. The amount of interest paid by the company is determined by the amount of debt earned and the interest rate charged by the creditor.

The amount of debt of the company is fluctuating because it is influenced by the payment of matured debt as well as new loan. This also has implications for fluctuating interest payments. In addition to being determined by the amount of debt, another factor determining the amount of interest payments is the debt quality of the enterprise. The creditor will be willing to provide a low interest rate if the debt is of good quality. The quality of the debt is determined by default or unpaid risk. The smaller the risk of default, then the debt can be said to be more qualified. (12) and (13) and many other researchers stated that the credit rating would determine the interest rate charged for the debt.

Cost of Debt (CoD) measurement can be done easily. Literature studies conducted to find several ways to measure (proxy) debt load is as follows:

1. The proportion of Interest on Average Debt is the most commonly used way is to calculate the proportion of interest borne by the company compared to the average debt obtained. [(14), (15), (16), (17), (18), (19), (20)]. The data required to calculate the proportion of interest can be obtained in the financial statements. 
2. Credit Rating (Bond Rating) although not used directly as a proxy of CoD, but credit rating is often used as an illustration of the condition of the debt because the rational credit rating greatly affect interest rates. A good rating will make $\mathrm{CoD}$ relatively smaller and vice versa. Credit Rating is a credit rating of a company issued by a rating agency. Some studies that use credit ratings such as (12) using the S \& $\mathrm{P}$ credit rating, (21) uses ratings from various sources available in the Compustat database, (13) using The Taiwan Corporate Credit Risk Index (TCRI).

\section{B. Earning Management (EM)}

Performance measurement is one of the most important aspects of successful enterprise management. Regarding performance measurement, profit becomes the most important part that is often used as the basis of assessment. This perspective drives profit into an object laden with interests. Profit informativity becomes one of the readers request financial statements in order to conduct an assessment of future profits and risks associated with the company. There is a considerable amount of empirical research related to the association between earnings and stock prices. Research (18) shows that the relationship between earnings and stock prices is higher than other estimates in financial statements such as sales, cash flow, inventory turnover, and so on.

The second role of accounting is related to company management. This arises in tandem with a clear separation between the owner of the company (shareholder) and management especially for the open company. Agency theory explains that along with the separation of the function in which management has a personal interest, the conformity between the company's objectives and the owner's goals can not be guaranteed. The financial statements, especially the calculation of profit into one of the gauges how management performs its functions as an agent of the owner. Based on that (22) states that one of the functions of the financial statements is to limit management to act in the interests of management.

The definition of Earning Management (EM) varies considerably depending on the underlying perspectives of the expert trying to define the definition. Some of these meanings are negative while others are positive. The notion is complementary, so it is difficult to make a complete definition and cover all aspects of EM. In general, the definition of EM can be divided into three groups: the definition that views the EM as a bad action (a negative point of view), a definition that views EM as an action that aims to increase firm value (positive), and a neutral definition.

From a negative point of view of the EM, it can be said that EM is an action that uses various mechanisms aimed at misinterpreting the financial statements in interpreting the financial statements for management purposes. This will reduce the transparency and informativeness of the financial statements. In this sense EM is an action that should not be done and will be a loss or cost to investors. On the other hand, some experts view EM as an action that can increase the value of the company. This understanding explains that EM is an opportunity the manager conveys her expectations through the information she has about future cash flow. The assumption that management did EM to share private information to the public was also submitted by (23).

Differences in outlook on EM are also evident from studies conducted within the EM area. The study, which tends to be in the opportunistic earning management type, concludes that EM is driven by management's desire to obtain higher (24), avoiding loss reporting and profit decline (25) and other research. The EM action in this negative perspective is carried out by management by making decisions that alter the financial statement information so that the published report describes the company in a condition consistent with the expectations of external parties in which the conditions tend to benefit. In this perspective, earnings management has violated the purpose of financial reporting is to present useful information in decision-making of interested parties.

\section{Implementation of International Financial Reporting Standard (IFRS)}

The development of business that leads to globalization has pushed the need for reporting standards so that the financial statements generated by the company can be understood globally. The issue of standardization is a major concern that encourages accounting stakeholders to seek a breakthrough to achieve that goal. After attempting various mechanisms, adoption and harmonization of International Financial Reporting Standards (IFRS) became the way forward to encourage the standardization of financial statements.

Gatsios (10) states that IFRS is a set of accounting standards issued by the International Accounting Standards Board (IASB) aimed at producing a high quality typical model for international accounting standards to provide information to users of financial statements. Ball (26) states clearly that the presentation of financial statements based on IFRS will make the financial statements more reliable by investors because it is easy to understand so as to reduce information asymmetry. Lee (27) expressed a similar opinion that international standards will increase disclosure of information that reduces information asymmetry and thus reduces risk.

In addition to standardization issues, IFRS leads to the improvement of the quality of the company's financial statements. Epstein (28) say that IFRS requires a high standard, transparency, and capability compared with other financial statements to help investors in global markets and other financial statement users. Turkey (8) emphasizes one of the benefits of IFRS's focus on the fair value concept by saying that the concept of fair value facilitates investors who need the most up-to-date information in their decision-making as they understand the company's last condition for cash forecasting. The two opinions above conclude that IFRS implementation will improve the quality of financial statement information.

Based on the above, theoretically can be said that the implementation of IFRS can encourage the reliability of financial statements because the information presented more informative and updated. Conceptually this will reduce information asymmetry sourced from information differences that are known by management than information that can be 
obtained by investors including one of the financial statement information. This theoretical concept has encouraged various studies to test these allegations.

Several studies focused on examining the impact of IFRS implementation on the company. Li's research (29) and (30) show that the implementation of IFRS encourages a decrease in the cost of equity borne by the firm. Different results are shown by Gao (7) that disclosure of new information presented as a result of IFRS implementation can not improve investors' predictive capabilities.

Turkish Research (8) states that IFRS implementation contains key factor factors that can reduce information asymmetry, thus lowering the cost of equity. Mohammadrezaei (9) conducted a literature study and concluded that the majority of research concludes that IFRS implementation reduces information asymmetry which reduces cost of equity but still recognizes that some research has led to different conclusions.

\section{CONCEPTUAL FRAMEWORK}

\section{A. Effect of Earnings Management on Cost of Debt}

Earning management actions by management by utilizing their access to discretionary accruals will degrade the quality of information so as to enhance information asymmetry. The results of (31) specifically gives conclusions that make a significant contribution in the formation of this research is that earning management gives a positive influence on cost of equity either directly or through information asymmetry. Other studies (32), (33), and (34) yield the same conclusion that earning management has a positive effect on cost of equity. Bhattacharya (1) also provides a complete picture of the overall aspects of earning management that make financial reports less informative. Research Miller and Martinez (35) who examines the relationship of earning management with debt concluded the negative effect of earnings management on credit rating, which means earning management has a positive effect on cost of debt. The study is in line with (36) who found empirical evidence that rating agencies will lower credit ratings if it detects management earning management.

However, (37) needs to be considered because it gives different results while conducting research with span of up to 30 years with the number of samples reached 6,076 companies actually resulted in the conclusion that there is no effect of income smoothing one way from earning management to cost of equity. Arya (38) who also conducts research in the United States finds the fact that earning management actions by managers do not always adversely affect investors. Fattouh(39), which examines the relationship of earning management with cost of debt also found the conclusion of no effect of earning management on the determination of cost of debt.

Based on the above, it is relatively difficult to estimate the impact of earning management on cost of equity. The results of these studies provide random results. There are some allegations that may cause this. First, the management's earning management action has a goal that varies between supplementing earning management and utilizing earning management for personal benefits (opportunistic earning management). Second, there are allegations how some methods of measuring earning management is not always in accordance with the conditions so it can not detect earnings management. To address some of the above assumptions, this study as described previously will integrate some earning management measurements. Based on the above explanation above, this research is still built on hypothesis that earning management action will have positive effect on cost of equity and cost of debt.

\section{B. Influence Implementation International Financial Reporting Standards (IFRS)}

Implementation of International Financial Reporting Standard (IFRS) will be used as a subset variable forming sample. This means that the researchers suspect there will be differences in influence between variables studied before and after the implementation of IFRS. This is driven by the IFRS development concept that seeks to reduce information asymmetry $[(26),((27,28)]$. The decrease in information asymmetry is derived from improving the quality of information and more complete disclosure. Not only have an effect on information asymmetry, but IFRS implementation based on various empirical studies is also able to decrease cost of equity and cost of debt $(29,30)$

The separation of this sub-sample is also very much in line with the results of (9) and (8) that there are significant differences in accounting practice in the areas studied in each of these studies. Due to the compatibility between these various empirical studies with the objective of IFRS implementation to reduce information asymmetry then this research will conduct multigroup procedure to obtain empirical evidence that implementation IFRS gives a difference for the influence between the variables studied. This procedure will be performed for all pathways to and from the information asymmetry variable.

\section{METHODOLOGY}

This study was conducted on manufacturing companies listed on the Indonesia Stock Exchange during the period of observation 2007 to 2016. The sample companies were selected as many as 129 companies with the number of observed financial statements of 1,161 10-year financial statements. The $\mathrm{CoD}$ measurements in this study will follow the measurements used by various studies such as (14), (40), (16), (15), and others. The formula used is:

$$
\mathrm{CoD}=\frac{\text { Interest Expense }}{\text { Average Interest Bearing Note }} \times 100 \%
$$

Approach measurement of Earning Management (EM) will use approach built by (41) that is Business Model, that is as follows:

$\mathrm{TA}_{\mathrm{i}, \mathrm{t}}$

$$
\begin{aligned}
& =\operatorname{lnt}+\frac{\left(\beta_{0}+\beta_{1} \Delta \operatorname{REV}_{i, t}+\beta_{2} \Delta P \mathrm{PE}_{\mathrm{i}, \mathrm{t}}\right)}{\mathrm{A}_{\mathrm{i}, \mathrm{t}-1}}+\beta_{4} \operatorname{ROA}_{\mathrm{i}, \mathrm{t}-1}+\beta_{5} \mathrm{NCWC}_{\mathrm{i}, \mathrm{t}-1}-\beta_{6} \overline{\mathrm{NCWC}}_{i, t-1}+\beta_{7} \\
& \operatorname{NCWC}_{i, t-1} x \Delta \operatorname{REV}_{i, t}+\beta_{8} \operatorname{dep}_{i, t-1}+\beta_{9} \operatorname{dep}_{i, t-1} P P_{i, t}
\end{aligned}
$$


$\mathrm{TA}_{\mathrm{t}}$

INT

: Total Accrual perusahaan i pada period t.

$\triangle \mathrm{REV}_{\mathrm{i}, \mathrm{t}}$

$\mathrm{PPE}_{\mathrm{i}, \mathrm{t}} \quad$ : Property, Plant, and Equipment perusahaan i

: Intercept atau konstanta pada periode $\mathrm{t}$

$\mathrm{A}_{\mathrm{i}, \mathrm{t}-1} \quad:$ Total Asset perusahaan i pada periode $t-1$.

$\mathrm{ROA}_{\mathrm{i}, \mathrm{t}-1} \quad$ : Return on Asset (ROA) perusahaan i pada periode $\mathrm{t}-1$

$\mathrm{NCWC}_{\mathrm{i}, \mathrm{t}-1} \quad$ : Non Cash Working Capital (NCWC) (Aktiva

lancar dikurangi hutang lancar dengan

mengeluarkan proporsi hutang jangka panjang

yang akan segera jatuh tempo dank as) yang

dideflasikan dengan asset periode sebelumnya)

$\overline{\mathrm{NCWC}}_{\mathrm{i}, \mathrm{t}}$

$\mathrm{i}, \mathrm{t}-1$ : Normal Non-Cash Working Capital yang

dihitung dengan rumusan berikut

$$
\overline{\mathrm{NCWC}}_{\mathrm{i}, \mathrm{t}-1}=\frac{1}{3} \sum_{\mathrm{k}=2}^{4} \mathrm{NCWC}_{\mathrm{i}, \mathrm{t}-\mathrm{k}}
$$

Dep $\quad$ : Depreciation rate (Beban depresiasi dibagi PPE)

Hypothesis testing will be used with regression analysis whereas to see the effect of IFRS implementation will use multigroup analysis (42).

\section{DISCUSSION}

This research is a preliminary research so that the developed model is relatively simple. The focus of this research is related to earnings management, debt costs, and IFRS implementation. Before conducting further analysis, a descriptive analysis of these variables is performed. This is done to obtain more complete framework for the next stage of analysis.

Earning management practices decreased slightly after IFRS implementation. This is evident from the declining discretionary accrual value calculated using the business model (41). The decrease in value is particularly evident during grouping of samples before and after the application of IFRS. The IFRS implementation period prior to 2012 has a higher average value of discretionary accruals over the next period. Although it can not be said that this is really an impact of IFRS implementation, it is in line with one of the objectives of IFRS implementation that wants to reduce information asymmetry that increases investment risk.

On the other hand, the value of Cost of Debt $(\mathrm{CoD})$ also decreased in the period after IFRS implementation. In this case, there is indeed potential for inaccurate analysis because the interest rate trend has decreased along with the Indonesian economy leading to low-interest rates. To minimize analysis error, a comparison analysis of the BI rate difference with the average of debt interest rate before and after IFRS implementation will be conducted. Based on this, there was a decrease of $5.5 \%$ to $4.6 \%$ from before and after IFRS impedation. The smaller value of the difference indicates that the risk premium demanded by the investor against the uncertainty that will be incurred by the decline. This means investors are increasingly able to pass rational estimates of the risks associated with their investments.

In the analysis of earnings management relationship to the cost of debt obtained data test results indicate that earnings management significantly influence the cost of debt with a significance value of 0.032 . It means that overall both before and after the implementation of IFRS there is influence of earnings management to the cost of debt. Furthermore, to find out whether there are differences in the relationship pattern between the two variables after the application of IFRS, multigroup testing where the regression coefficients for the regression analysis before and after the IFRs implementation test the difference. Based on the multigroup analysis, it can be concluded that there is a difference of influence of earnings management to the cost of fairy debts before and after the ban IFRS. This is in line with previous research that has been summarized by Mohammaderazei (9).

\section{CONCLUSION}

Based on the results and discussions that have been submitted earlier, it can be concluded that the implementation of IFRS has an impact on declining earnings management practices undertaken by the management of manufacturing companies. This also has an impact on the decline in the value of Cost of Debt which means the risk premiums imposed on investment activity decreased. On the other hand the effect of earning management on cost of debt changes before and after the implementation of IFRS.

\section{References}

[1] Bhattacharya U., Daouk H., Welker M., "The world price of earnings opacity". Vol. 78, Accounting Review. 2003. p. 641-78.

[2] Zeren F., Konuk F., "Testing the random walk hypothesis for emerging markets: evidence from linear and non-linear unit root tests". Rom Econ Bus Rev. 2013;8(4):61.

[3] Sanyal P.K., Gahan P., Gupta S. Sen, "Market efficiency in emerging economics: An empirical analysis". Globsyn Manag J. 2014;8(1/2):2238.

[4] Almudhaf F.W., AlKulaib Y.A., "Are civets stock markets predictable?" Acad Account Finance Stud J. 2013;17(3):1-12.

[5] Nekrassov A., "Cost of equity and risk in earnings components". University of Minnesota; 2008.

[6] Turki H., Wali S., Boujelbene Y., "The effect of IFRS mandatory adoption on the information asymmetry". Cogent Bus Manag. 2016;3(1):1-19.

[7] Mott G., "Accounting for non-accountants: a manual for managers and students". Kogan Page Publishers; 2012.

[8] Wu T.Z., Lee P.S., "Information transparency, corporate governance, and convertible bonds". J Appl Bus Res. 2014;30(2):541-55.

[9] Hashim H.A., Amrah M., "Corporate governance mechanisms and cost of debt: evidence of family and non-family firms in Oman". Manag Audit J. 2016;31(3):314-36.

[10]Zhu F., "Corporate Governance and the cost of capital: an International study". Int Rev Finance. 2014;14(3):393-429. 
[11]Juniarti, Natalia T.L., "Corporate Governance Perception Index (CGPI) and Cost of Debt". Int J Bus Soc Sci. 2012;3(18):223-32.

[12]Lorca C., S??nchez-Ballesta J.P., Garc??a-Meca E., "Board Effectiveness and Cost of Debt". J Bus Ethics. 2011;100(4):613-31.

[13]Francis J., LaFond R., Olsson P., Schipper K., "The market pricing of accruals quality". J Account Econ. 2005;39(2):295-327.

[14]Pittman J.A., Fortin S., "Auditor choice and the cost of debt capital for newly public firms". J Account Econ. 2004;37(1):113-36.

[15]Hodges C.W., Lin B., Lin C-M., "Product market competition, corporate governance, and cost of capital". Appl Econ Lett. 2014;21(13).

[16]Watts R.L., Zimmerman J.L., "Positive Accounting Theory: A Ten Year Perspective". Account Rev. 1990;65(1):131-56.

[17]Ronen J., Yaari V., "Earnings management". Demski J.S., editor. Springer; 2008.

[18]Bergstresser D., Philippon T., "CEO incentives and earnings management". J finance econ. 2006;80(3):511-29.

[19]Park M.S., Park T., "Insider sales and earnings management". J Account Public Policy. 2004;23(5):381-411.

[20]Lee E., Walker M., Christensen H.B., Zhao R., "Mandating IFRS: Its Impact on the Cost of Equity Capital in Europe". Vol. 9, Journal of International Accounting Research. 2010. 58-59 p.

[21]Epstein B.J., Mirza A.A., "Interpretation and Application of IAS". WileyIAS; 1999.

[22]Li S., "Does mandatory adoption of international financial reporting standards in the European Union Reduce the cost of equity capital?" Account Rev. 2010;85(2):607-36.
[23]Bhattacharya N., Ecker F., Olsson P.M, Schipper K., "Direct and mediated associations among earnings quality, information asymmetry, and the cost of equity". Account Rev. 2012;87(2):449-82.

[24] Kim J.B., Sohn B.C., "Real earnings management and cost of capital". J Account Public Policy. 2013;32(6):518-43.

[25] Strobl G., "Earnings manipulation and the cost of Capital". J Account Res. 2013;51(2):449-73.

[26]Patro A., Kanagaraj A., "Is Earnings Management a Technique to Reduce Cost of Capital?" Exploratory Study on Indian Companies. J Mod Account Audit. 2016;12(5):243-9.

[27] Shen C.H., Huang Y.L., "Effects of earnings management on bank cost of debt". Account Finance. 2013;53(1):265-300.

[28] Mc Innis J., "Earnings smoothness, average returns, and implied cost of equity capital". Vol. 85, Accounting Review. 2010. p. 315-41.

[29] Arya A., Glover J.C., Sunder S., "Are unmanaged earnings always better for shareholders?" Vol. 17, Accounting Horizons. 2003. p. 111-6.

[30]Fattouh I.H., Ghafeer N.A.M., Rahman A.A.A.A., "The Impact of Practicing Earnings Management on Borrowing Costs in Pharmaceutical Companies listed in Amman Bursa". Int J Information, Bus Manag. 2015;7(4):307-22.

[31]Farooq O., Derrabi M., "Effect of corporate governance mechanisms on the relationship between legal origins and cost of debt: Evidence from the Middle East and North Africa (MENA) Region". African J Bus Manag. 2012;6(7):2706-14.

[32] Ghozali I., Latan H., "Konsep, Teknik, Aplikasi Menggunakan Smart PLS 3.0 Untuk Penelitian Empiris". BP Undip. Semarang; 2015. 